\title{
Biodegradable Hard Tissue Implants
}

\author{
Erkin Aydin a and Vasif Hasircia, ${ }^{\mathrm{a}, \mathrm{b}}$ \\ a METU, BIOMAT, Department of Biotechnology, \\ Biotechnology Research Unit, \\ 06531 Ankara, Turkey \\ ${ }^{b}$ METU, BIOMAT, Department of Biological Sciences, \\ Biotechnology Research Unit, \\ 06531 Ankara, Turkey ${ }^{1}$
}

Received 4.03.2010, received in revised form 11.03.2010, accepted 18.03.2010

Aging population and decreased physical activity due to increased life standards are two prevalent and inevitable factors that cause decrease in bone mineral mass, bone quantity, and muscle strength in the population. These consequences increase the incidence of bone fracture throughout the life of individuals. Although the bone has a great regenerative capacity compared to most other tissues or organs in the body, a proper healing of the bone requires appropriate alignment and fixation of fractured fragments throughout the process. There are different techniques and tools to provide bone substitutes with those properties. Most of the available fixation tools are made from non-eroding metals due to their inherent stiffness and toughness, the properties necessitated by the load bearing function of the skeletal system. Ideally, however, an implant should be temporary and be eliminated from the body as soon as its function is no longer necessary due to potential risks like late stage infection, bone resorption or immune reactions. For bone implants, due to the need for stabilization of fixation devices to the surrounding bone using screws or nails, removal operations may cause severe morbidity to the newly repaired fracture site. Another equally important problem with use of metal fixation devices is their superior mechanical properties that outweigh those of bone, lead the newly forming bone tissue not to be subjected to mechanical stimulation, which is a necessary requirement for bone forming machinery. Considering these problems, different biodegradable or bioerodible materials were suggested to be used in the production of temporary bone fracture fixation devices. This paper reviews the developments and trends in the field of biodegradable hard tissue implants, available materials, and their suitability to the host bone tissue.

Keywords: Hard tissue implants, biodegradable polymers, bioerodible ceramics, biodegradable metals, biomechanics, biocompatibility.

\section{Introduction}

Bone is a dynamic tissue in that bone formation and resorption occurs repeatedly by the action of osteoblasts and oteoclasts, respectively. The balance between these two processes is maintained by the current state of the body and physical activity. This is also valid in healing and remodeling of a fracture site but with more parameters, including mechanical stimulus and condition and location of the fracture site. At this point, the mechanical properties are critical because too rigid fixation causes problems at

*orresponding author E-mail address: vhasirci@metu.edu.tr

(C) Siberian Federal University. All rights reserved 
the later stages of healing process. If there is not enough load transfer to the newly forming tissue, which is called stress shielding, new bone formation stops while bone resorption continues and this causes an osteoporotic and mechanically weak bone (Paavolainen et al., 1978). Therefore, the early advantages of standard metallic fixation devices turn out to be problem in later stages of the bone healing process. In this context, biodegradable implants would be better suited to the loading requirements of the bone. By controlling the degradation rate and thus the loss of intrinsic stiffness, implants can be tailor-made to satisfy the load transfer requirements of the newly forming bone.

\subsection{Bone Healing}

Bone healing is a complicated yet controlled process, and is a more regenerative process than simple repair. Bone fracture results in an immediate hemorrhage and clot formation at the fracture site due to disruption of blood vessels at and nearby sites. Healing process starts with removal of the clot and the tissue and cell debris. Then fibroblasts residing in the inner layer of the periostum migrate and proliferate towards the injured site, to lay down a fibrous collagen matrix, called callus. It forms at both ends of the fractured bone segments and bridge the ends. Cartilage then forms at the site of the callus where there is not enough blood supply, followed by calcification by the action of osteoblasts. During this phase, cartilage is transformed first into trabecular bone and then to compact bone. In this period, new vascularization takes places, however, if the fracture site is not properly fixed, the newly formed vessels could be destroyed, retarding the healing process, and resulting in formation of a fibrous callus. Therefore, it is very important to stabilize the fracture site to achieve early vascularization. For this, use of the current gold standard metallic fixation devices is very appropriate. Their inherent strength and stiffness easily supports the initial high mechanical strength requirement. However, biodegradable fracture fixation implants, mostly of polymeric origin, cannot meet this criterion due to the intrinsic low mechanical properties of the polymers. Thus, polymeric implants cannot be produced in compact geometries unlike their metal counterparts, and fixation is problematic especially at the sites of restricted access or with small surfaces. This inappropriately low initial strength is the reason, why such biodegradable polymeric implants cannot be applied in fixation of fractures of weight bearing bones and need to be improved.

\subsection{Bone Augmentation Devices}

Orthopedic implants, such as hip, spine, shoulder, and knee prostheses are mostly used in cases of loss of bone function as a result of degenerative joint diseases. These implants are meant to substitute the mechanical function of the tissues they replace and, therefore, their service life must be long, requiring them not to be manufacturedfrombiodegradablematerials. There are also those temporary implants which augment healing of fractured bones by helping to carry the body's weight which cannot be borne due to the discontinuity caused by the fracture. Fracture fixation implants, e.g., plates, intramedullary nails, pins and screws, are included in this category. They are also used to stabilize the bone fragments in the correct shape during the healing period. In order not to interfere with the normal state and functioning of the surrounding tissues continuously and for patient comfort, it is the best that they are eliminated from the body soon after tissue healing is completed. This is because degradable foreign materials within the body, like metals or polymers, always have the potential to cause problems due to their degradation products including metal particles from corrosion, 
inflammation, delayed infection (Bayston et al., 2007), and accumulation of material debris at injury site resulting in tissue damage (Kim et al., 1997; Mine et al., 2010). Therefore, if the implant cannot be biologically eliminated, this is done with surgery, which means another trauma for the injury site that increases the associated risk of infection, causes further cost, loss of work days and patient discomfort (pain). In fact, in order to avoid these problems, sometimes surgeons allow implants to remain in the body for the lifetime of the patient if a permanent implant is not foreseen to constitute a major problem.

For the time being, bone, cartilage, and joint augmentation or replacement, and fixation of fractures of the load-bearing bones are achieved using metals (e.g. stainless steel, titanium) and metal alloys (e.g., nickel/titanium, zirconium, cobalt/chromium) (Niinomi, 2008; Fleck and Eifler, 2009; D'Antonio and Sutton, 2009;), polymers (e.g., polyetheretherketone) (Moon et al., 2009), or ceramics (e.g., aluminum oxide, glass-ceramics) (Thomas et al., 2005; D'Antonio and Sutton, 2009). All of these materials are essentially non degradable and they are chosen primarily due to their abilities to withstand the stress - strain levels, to which the bone is exposed during normal physical activities. For the fixation of fractures for some low or non-load bearing bones, there are some biodegradable implants including plates, rods, pins, and screws already on the market.

\section{Bone Tissue Engineering}

To overcome the inherent problems of autografting and allografting, tissue engineering has emerged as a significant research area in the context of regeneration of bone as well as other tissue and organs. Basically, it consists of obtaining tissue specific cells from a patient's own body, growing them (in culture) on threedimensional scaffolds that mimic the tissue in question, and placing them into the defect site (Shin et al., 2003). The properties of the scaffold are important: it must possess high porosity and a high degree of interconnectivity between the pores so that cells can enter, colonize the depths of the material, and interact with each other. Similarly, tissue fluids carrying nutrients, and local and systemic factors can enter and leave the construct to guide and support cellular growth. The scaffold must also be bioabsorbable such that it is eliminated gradually as the tissue heals, while retaining appropriate level of mechanical properties in order to be able to serve its function until the tissue heals.

Bone tissue engineering is specifically attractive in complex bone fractures, where there is loss of bone material and the gap between the fragments cannot be filled by the body itself. The limit beyond which the bone cannot heal by itself is called critical size bone defects, and in order to heal these defects some filling material, preferably osteoconductive and/or osteoinductive, is required. For optimal remodeling of the newly formed tissue, the implant needs to be replaced by the healing bone, thus necessitating the use of biodegradable materials. There are different approaches to filling such gaps; some use only porous implants, so that osteoblasts of the body migrate in, proliferate and deposit their extracellular material on the way to healing (Hutchens et al., 2009) while some others use the tissue engineering approach where the patient's own mesenchymal stem cells are seeded in the porous filler constructs which might be allowed, ex vivo, to differentiate into osteoblasts within the constructs, and form new bone tissue after implantation, accelerating and facilitating bone healing. To those tissue engineering constructs, controlled delivery systems of bone morphogenic proteins (BMP) may be added to activate the bone cells to form bone and/or enhance remodeling (Basmanav et al., 2008; Yilgor et al., 2009), 
likely by inducing blood vessel formation. Tissue engineering approach has to use biodegradable materials, mostly polymers and their composites with different ceramics (calcium phosphates), but because of the high porosity requirement for cell penetration, those scaffolds do not possess the mechanical strength needed to serve as an ultimate solution for bone fracture fixation. Therefore, tissue engineering approach is not the main concern of this article.

In order to allow fluid drain and cell entrance, and achieve attachment and proliferation for later tissue remodeling, tissue engineering scaffolds must have an inherent high porosity and interconnected pores (Karageorgiou and Kaplan, 2005). Though, high porosity adversely affects the mechanical properties of materials and is especially important for the bone tissue which is under continuous loading. Mechanical stimulus is an inevitable necessity for proper bone regeneration and any tissue engineering construct will be under the effect of it until it is absorbed. Designing highly porous, mechanically suitable scaffoldsisparticularlyimportantwhentheimplant has to be biodegradable. Therefore, generally the mechanical properties of the biodegradable scaffolds are compromised. To satisfy these requirements, a biodegradable composite ceramic scaffold composed of $\beta$-tricalcium phosphate ( $\beta$ -TCP) matrix and calcined hydroxyapatite (HA) nanofibers was prepared for load bearing bone applications (Ramay and Zhang, 2004). A high porosity (ca. $73 \%$ ) composite was obtained with a maximum compressive strength of ca. $10 \mathrm{MPa}$ when $5 \%$, w/w HA nanofibers were used. This made the scaffold comparable to cancellous bone, since such material can only be implanted along with other supportive elements like a bone plate or intramedullary rod.

An in vivo study (rat femoral segmental defect model) demonstrated the applicability of a biodegradable polymer/ceramic composite, poly(propylene fumarate) (PPF) and tricalcium phosphate (TCP), to serve as a temporary bone support while rhBMP-2 release was achieved from a porous dicalcium phosphate dehydrate carrier system (Chu et al., 2007). The implant was constructed of a hollow tube made from non-porous polymer/ceramic composite, to be placed in the intramedullary cavity of the defected femur, where a porous BMP-2 carrier is integrated into a hole drilled in this implant. The initial compressive strength was $23 \mathrm{MPa}$, decreased to $12 \mathrm{MPa}$ after 12 weeks in phosphate buffered solution at $37{ }^{\circ} \mathrm{C}$. Although the authors state that there is no need for bone plate or other means of stabilation due to sufficient inherent strength of the implant, they placed a (nondegradable) stainless steel $\mathrm{K}$ wire through the internal cavity of the hollow tube-shaped implant in order to share the load. Therefore, even a nonporous biodegradable implant might not have sufficient mechanical strength for bone fixation applications.

\section{Biodegradable Polymeric \\ Hard Tissue Implants}

Fixation of osteotomized and fractured bone segments is achieved using internal rigid fixation devices including plates and screws, and the gold standard material for these is titanium (Hasirci et al., 2000; Cheung et al., 2004) due to its inherent stiffness and biocompatibility. However, this everlasting stiffness may cause the stress-shielding phenomenon mentioned earlier, resulting in osteoporotic bone and skeletal growth retardation in pediatric patients (Yaremchuk and Posnick, 1995). Therefore, in order to overcome the problems associated with metal fixation devices, a number of polymer-based biodegradable plates and screws were devised and a number of them are already available and have some clinical experience. A detailed mechanical evaluation of 7 currently available biodegradable osteofixation 
<smiles>CC(=O)COC(C)(C)C(=O)COC(C)(C)C(C)(C)C</smiles>

Glycolide

poly(glycolide)

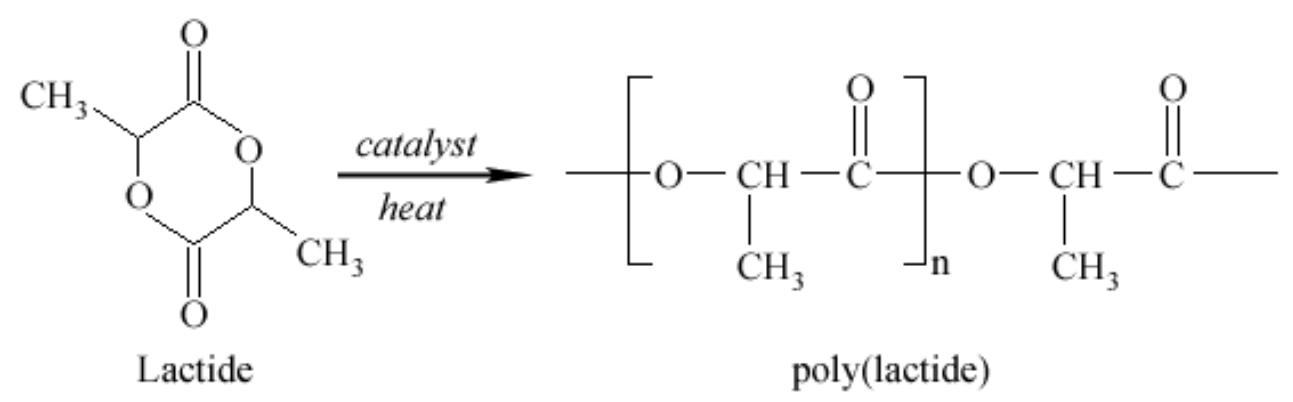

Fig. 1. Synthesis of PGA and PLA via ring opening polymerization

systems and comparison of them with 2 titanium counterparts were reviewed by Buijs et al. (2007).

\subsection{Polylactide/Glycolide Family}

\section{As Biodegradable Hard Tissue Implants}

Despite the presence of a large number of synthetic or natural origin biodegradable polymers studied in the context of biomaterials research (e.g. polylactide (PLA), polyglycolide (PGA), poly(lactide-co-glycolide) (PLGA), poly( $\varepsilon$ caprolactone) (PCL), polyhydroxybutyrate (PHB), poly(hydroxybutyrate-co-hydroxyvalerate) (PHBV), chitosan, poly(2-hydroxyethyl methacrylate) (PHEMA), collagen, and hyaluronic acid), only a few of them are suitable as implant materials to be used in hard tissue regeneration due to stringent mechanical property requirements.

Historically, the most extensively studied biodegradable polymer as a biomaterial is lactide/ glycolide family of polymers and these efforts have resulted in the approval of their use within the body by FDA. Different formulations of PGA,
PLA and PLGA have been studied extensively for this context. PGA is the simplest linear aliphatic member of the family and was used to produce the first completely absorbable synthetic suture in the 1960's. The monomer glycolide is synthesized by dimerization of glycolic acid and then PGA is formed via ring opening polymerization (Fig. 1). It is a highly crystalline polymer (45-55\%), and therefore, it is not soluble in most organic solvents. PGA fibers have high tensile strength $(70-138$ $\mathrm{MPa}$ ) and modulus (6.9 GPa), and their high stiffness prevents easy processing and interferes with the properties of resulting product (Perrin and English, 1997). Therefore, only a small number of products were prepared using PGA. Their copolymers with lower stiffness values are more suitable for orthopedic applications, and, therefore, are used instead of PGA.

PLA is obtained through ring opening polymerization of lactide (Fig. 1); there are two lactide isomers, namely $\mathrm{D}$ and $\mathrm{L}$ forms. The stereopolymer PLLA is semicrystalline, with a crystallinity of around $37 \%$, and has the highest 
inherent tensile strength and modulus (2.7 GPa) among polylactides. Instead, PDLA is an amorphous polymer with lower tensile strength and modulus (2.0 GPa). On the other hand, PLLA needs a much longer time for degradation in the body than PDLA does.

\subsection{Degradation of Lactide and Glycolide Polymers}

In vitro and in vivo degradation of PLGA polymers have been studied by numerous researchers during the last three decades. Simple chemical hydrolysis of the backbone is the predominant mechanism of degradation of these polymers. Semicrystalline polymers have repeating units that go into tight associations with each other, producing dense regions throughout the polymer backbone, called crystallites. Although this occurs due to steric effects, i.e. tacticity, these crystalline regions are tightly held together so that they act like chemical crosslinks and lead to increase in tensile strength and stiffness.

In semicrystalline polymers, water penetrates the bulk of the polymer material and attacks the chemical bonds in the amorphous phase. Backbone is continuously fragmented into smaller chains until those oligomers are soluble in aqueous media and then eliminated by the excretory system. This causes an initial reduction in the molecular weight without a loss of physical integrity of the device due to the fact that the device matrix is held together by the crystalline regions. Afterwards, water further fragments the implant and loss of physical properties follows. The water penetration into the crystalline phase is very limited, and so is the hydrolytic degradation at crystalline regions. The result is large amounts of independent small and rough, highly crystalline and resistant remnants. Such particles are known to be highly inflammatory and may cause post implantation responses (Bergsma et al., 1995).
Bergsma et al. (1995) conducted a study on patients with zygomatic fractures that received PLLA plates and screws for up to 5.7 years, even after which there were highly crystalline PLLA particles internalized by various cells and also remnants of degraded PLLA material surrounded by a dense fibrous capsule. Although those particles do not cause irritation or injury to cells, there were swellings at the implantation sites in some of the patients. These give some ideas about the fate of those materials within the body, though, it is to be reminded that in practice, host reaction depends on different factors including implant size and shape and implantation site.

Additionally, byproducingPLAwithdifferent ratios of chiral lactides or their copolymers with glycolide, crystallinity, degradation rates and mechanical properties of the polymers can be adjusted to particular needs of the implants.

\subsection{Biodegradable Bone Plates}

and Screws for Oral

and Maxillofacial Surgery

Lactosorb ${ }^{\circledR}$ (Biomet Microfixation Inc, USA) is a PLLA/PGA (82:18) copolymer based craniomaxillofacial fixation system that is composed of plates of different geometries and screws, both of which are absorbable. According to the product catalog of the manufacturer, this system has been used in more than 50,000 craniomaxillofacial surgeries since the first release at 1996. A 2004 study reviewed results of 1883 pediatric craniofacial surgeries in which resorbable plate and screw fixation systems were used (Eppley et al., 2004). Operations by 12 surgeons who used Lactosorb ${ }^{\circledR}$ as the fixation system for a 5 -year period were evaluated. The complications resulting from these actions were: infection $(0.2 \%)$, device instability due to postoperative trauma $(0.3 \%)$, and self-limiting local foreign body reactions $(0.7 \%)$. The overall reoperation rate due to device-related problems 
was $0.3 \%$ of the cases, which is less frequent than observed with metallic bone fixation systems. Authors stated that resorbable bone fixation for the rapidly growing cranial vault of infants has fewer potential complications than traditional metal plate and screw fixation systems.

A cranial/maxillary bone union healing requires approximately 8 weeks and after this duration Lactosorb plates were claimed by the manufacturer to retain $70 \%$ of their initial strength, making them appropriate for use in fractures of this area (Lactosorb brochure). Screws of this system show a $90 \%$ strength loss profile of 12 weeks, which is claimed to be compatible with the duration of normal healing process (Mitchell et al., 2005). Pietrzak et al. (2009) suggested a material with almost the same composition (85:15 lactide to glycolide molar ratio), higher inherent viscosity and smaller polydispersity to be used in patients where a delayed healing is foreseen. This new material had the same initial tensile modulus of $0.8 \mathrm{GPa}$ as the $82: 18$ PLGA, but the strength retention was longer (up to 44 weeks).

\subsection{Biodegradable Interface Screws}

In anterior cruciate ligament (ACL) reconstruction surgeries, one end of the ligament is fixed to the lower femoral head while the other to the upper tibial head, with one screw at each site. Along with the classical metal screws, there are now commercially available biodegradable screws especially popular in knee surgeries. Konan and Haddad (2009) wrote an extensive clinical review about the currently available commercial biodegradable screws for ACL reconstruction surgeries.

According to a randomized clinical trial on 85 patients having arthroscopic patellar tendon autografts (Barber et al., 1995), commercial PLLA interference screws showed essentially no difference in terms of ease of application or patient's healing period when compared to metal screws used in the same application. In a similar study, PLLA and titanium interference screws led to comparable results in 97 patients having bone patellar tendon autograft reconstruction of ACL (Keading et al., 2005).

PLLA has a crystallinity of about $37 \%$ and, thus, it is one of the most sturdy biodegradable polymers, making it suitable as bone implants. However, this is accompanied by a lowered degradation rate within the body. A study by $\mathrm{Ma}$ et al. (2004) showed that after interference screw fixation of hamstring autograft ACL reconstruction on two groups of 15 patients with 24 to 40 months follow-up, $83 \%$ of all implanted PLLA screws were found to be intact or only partially degraded. This situation increases the risk of late stage inflammatory reactions.

There are some other commercially produced biodegradable screws including the ones made from poly (D,L-lactide) (PDLLA), poly (D,L-lactide co-glycolide) (PLDLGA), and the composite poly (L-lactide) - $\beta$-tricalcium phosphate. They do their job fairly well, but one thing that is in common with all these examples is the lack of follow-up studies in terms of number of patients compared to the classical metal screws in use for a much longer duration (Konan and Haddad, 2009). Although their mechanical properties can match the healing profile of the tissue, the most important suspects about their use is the potential biologically adverse responses by the host and this is especially difficult to assess with in vivo studies due to the fact that such reactions are species specific.

\section{Bioerodible Ceramic Hard Tissue Implants}

Bone grafts are needed in orthopedic surgeries in cases with a bony defect and autologous bone, taken usually from the iliac crest, is still the gold standard in this respect. However, donor site morbidity and sometimes 
scarcity, the risk of infection, the pain and need of the secondary operation are the main factors that render this option not ideal. Use of allografts or xenografts are other options, however, this runs the risk of disease transmission and excessive host immune responses.

The logical option would be the use of a material that is free from risks associated with human- or animal-origin grafts, available in sufficient quantities, and produced with desired properties that would assist integration to bone and induce osteogenesis. Therefore, a large number of different bone graft materials have been produced until now from a variety of materials such as bioactive or inert ceramics, polymers, metals, and materials obtained from natural sources like corals.

Calcium phosphate derivatives are the most commonly used ceramic materials in bone regeneration studies, which are due to the fact that mineral constituent of bone is a calcium phosphate that is in the form of carbonate apatite. Current medical applications of calcium phosphate biomaterials consist of repair or augmentation of periodontal defects and alveolar bone, sinus lifts and tooth replacements, filling of large bone defects after tumor removal, spine fusions, and ear and eye implants (LeGeros, 2008). They are also used as scaffolds in tissue engineering of bone and dentin, as injectable bone cements, or as coatings on some metallic bone implants. Those ceramics have proven positive effects on bone regeneration due to their being osteoconductive, bioactive, and even bioresorbable. Interconnecting porosity can be achieved in such materials by use of porogens or by other means to promote cell attachment, proliferation, and differentiation and to serve as paths for fluid drainage. This is also crucial in bone tissue engineering applications; however, the inherent high brittleness of ceramics makes the porous forms of those materials very low in strength and in toughness, thus severely suppressing their clinical use (Yaszemski et al., 1996).

Production of different phases with different resulting properties of calcium phosphates is possible. The molar ratio of calcium to phosphate $(\mathrm{Ca} / \mathrm{P})$ can be in the range 1.5 to 2.0 . $\beta$-tricalcium phosphate $(\beta-\mathrm{TCP})(\mathrm{Ca} / \mathrm{P}: 1.5)$ and $\mathrm{HAP}(\mathrm{Ca} / \mathrm{P}$ : 1.66) are the mostly evaluated calcium phosphate ceramics. $\beta$-TCP is the most readily bioerodable member of the group whereas HAP is chemically very similar to the mineral constituent of bone. Grafts produced from a combination of these two forms are called biphasic calcium phosphates and are more effective in bone regeneration than the pure forms of either phase (Ramay and Zhang, 2004). This combination gives the implant the advantage of adjustable erosion rate.

Brittleness and low-fatigue resistance of calcium phosphate materials are the most important shortcomings that restrict their use in load-bearing applications. Fracture toughness is the ability of a material to resist fracture when containing a crack within the materials matrix, and it is an important property to be considered for virtually any engineering design. Fracture toughness of HAP is lower than $1 \mathrm{MPa} \mathrm{m}^{1 / 2}$, which is much lower than that human bone, which is 2 to $10 \mathrm{MPa} \mathrm{m}^{1 / 2}$. Furthermore, this value decreases linearly with increasing porosity (Suchanek, 1998). These indicate that a pure HAP implant would undergo a rapid failure above a certain stress, unlike the bone which shows a ductile fracture behavior. Thus, medical applications of ceramic materials are virtually limited mostly to filling large defects in bones.

Despite the mechanical disadvantages of calcium phosphates, there are certain areas of application where their high level of chemical and cellular bone compatibility can be used to an advantage. Since these materials are essentially bioerodible and their chemical compositions 
are very similar to those of bone, they can be easily used for void filling where cellular bone remodeling process uses them to regenerate the defect area. For example, self-setting bone cements containing calcium phosphate can be injected and allowed to set in the defect site after completely filling the gap and taking the form of the defect (Bohner, 2000). Furthermore, there are some forms of them in which a certain level of porosity can be obtained after setting in the defect zone to allow tissue ingrowth.

\section{Biodegradable Metal Hard Tissue Implants}

Use of metals as hard tissue implants is as ancient as the history of biomaterials due to the high compressive and tensile strength and modulus of metals. Through time, a large number of alloys were discovered, especially to increase their biocompatibility. The most important disadvantage of these materials is their long term presence in the body, which eventually ends with a complication necessitating their removal. Recent studies in the field are about the change their fate especially shortening their presence by use of degradable implants.

Biodegradable metals are especially made of magnesium alloys in which the material surface exchanges ions with the surrounding physiological medium. Dissolution occurs as a result of oxidation reactions and the ions that leave the metal react with water to form unreactive metal hydroxides or oxides. Magnesium is a naturally occurring metallic element and has important physiological functions in homeostasis like acting as a cofactor for many enzymes and also increasing the stability of DNA and RNA (Hartwig, 2001). Therefore, an efficient magnesium excretion system is present in the body and magnesium accumulation to toxic levels is not expected (Vormann, 2003). This is actually a prerequisite for considering the use of magnesium based biodegradable implants, because compared to other polymeric or ceramic materials, the degradation rate of magnesium based implants in the physiological environment is very rapid and the degradation products have to be rapidly eliminated in order to not cause problems.

Modulus of elasticity for magnesiumimplants is between $41-45 \mathrm{GPa}$, a value much lower than any of the currently available metallic implants (Staiger et al., 2006) but it is closer to modulus of elasticity of natural bone (10-30 GPa, Nagels et al., 2003), and, therefore a highly desirable property of hard tissue implants because this reduces stress shielding. Pure magnesium materials also have a low but appropriate compressive strength value of 100 MPa (100-130 MPa for bone).

\subsection{Biocompatibility of Magnesium Ions}

Magnesium is suggested to have a biochemical role in bone formation. Magnesium ion can form complexes with nucleic acids due to the negatively charged sugar-phosphate backbone of the latter, and electrostatically stabilizes base pairing and base stacking. Magnesium is not known whether it acts as gene regulator, however, it affects cell cycle in different ways (Wolf and Cittadini, 2003).

Pure magnesium in vivo degrades very rapidly, and this form cannot be used as a hard tissue implant. A very early attempt to use a pure magnesium bone plate failed in as early as 8 days due to heavy corrosion (Lambotte, 1932). A screw made from a simple magnesium-aluminummanganese alloy was reported to be absorbed completely in 120 days after implantation (McBride, 1938); obviously the mechanical properties became unsuitable much earlier. Although service life of such simple magnesium alloy implants are far shorter than complete healing of a bone fracture, lack of any systemic reactions or local inflammatory response and positive effect on callus formation at fracture site 
encouraged scientists to continue their research in developing longer-lasting magnesium alloys. A problem associated with the use of magnesium implants is the liberation of hydrogen gas in the chlorine rich tissue fluids, which occurs at such a high rate that the body cannot eliminate it. This leads to formation of gas cysts around the implant site, and in the worst case even cause gas gangrene (McCord, 1942). Magnesium alloys were abandoned, mainly due to this problem, after the stainless steel became available in the 1950's (Witte et al., 2005).

A recent article by Zberg et al. (2009) addresses this issue where they present a new glassy magnesium alloy containing calcium and zinc which is said not to cause hydrogen gas formation, in vivo. This is reported to be due to the formation of a zinc and oxygen rich passivating layer on the implant surface when the zinc content of the alloy is higher than a certain threshold value.

With the increased awareness of potential of biodegradable implants and discovery of advanced alloying techniques, research on the magnesium as an implant material is continuing. It was discovered that addition of rare earth elements also decreases the in vivo corrosion rate (Staiger et al., 2006). There have been many attempts to decrease the degradation rate of magnesium by evaluating different alloy combinations with zinc, calcium, yttrium, cadmium, manganese, and aluminum in order to obtain a mechanical integrity that would better match the healing profile of bone fractures ( $\mathrm{Gu}$ et al., 2009; Hänzi et al., 2009). Witte et al. (2005) studied in vivo degradation of new generation magnesium alloys after they prepared magnesium alloys containing two different aluminum and zinc ratios (3:1 Al: Zn $\mathrm{w} / \mathrm{w}$, called AZ31, and 9:1 Al:Zn w/w, called AZ91). They also prepared two magnesium alloys containing either yttrium or lithium and aluminum; both containing two different compositions of a rare earth metal mixture that is composed of cerium, lanthanum, neodymium and praseodymium (called WE43 and LAE442, respectively). They prepared implant rods and used a biodegradable polymer; self reinforced PLA, as reference. Rods were implanted into the femur of guinea pigs for 18 weeks. The study showed that surface of the magnesium alloys were coated with newly formed bone mineral that was in direct contact with the surrounding bone tissue, where new bone formation was significantly higher, than with polymer samples. Degraded mass of all magnesium implants was replaced by a thick layer of calcium. Hydrogen gas accumulation was much lower than the cases reported previously in the literature, and when removed by a syringe, this stopped accumulating after the first week. Rare earth metals stayed in the implant and were not detected in the surrounding bone. The most corrosion resistant alloy was LAE442, while others showed similar corrosion rates. These results suggest that magnesium alloys can be biocompatible, osteoconductive, with controllable degradation properties and, thus, suitable for hard tissue implantation.

\subsection{Mechanical Properties}

\section{of Magnesium Alloys}

There are other problems associated with magnesium alloys to be solved. One of them is the initial, right after implantation, strength reduction of magnesium alloys. Zhang et al. (2006) reported that with only $6 \%$ loss of initial weight, bending strength of a magnesium-zinc alloy decreased from $625 \mathrm{MPa}$ to $390 \mathrm{MPa}$, a decrease to almost $60 \%$. A logical approach to increase the service life of magnesium alloy implants is to use an implant material with inherent strength higher than actually desired. Also, magnesium alloys usually have an inherent non-uniform surface corrosion pattern, causing pits on the surface (Witte et al., 2005, Gu X et al., 2009, Zhang S 
et al., 2009). These tend to spread laterally and produce a higher implant surface area that is more prone to attack by ions of the surrounding tissue fluid, resulting in an even higher degradation rate. Moreover, those pits lead to particle losses and decrease the mechanical strength (Song and Atrens, 2003).

Most of the magnesium alloys designated as biomaterial contain aluminum and/or rare earth elements. However, it is well documented that aluminum can harm osteoblasts $(\mathrm{Ku}$ et al., 2002) and neurons, and is also associated with Alzheimer's disease (El-Rahman, 2003). Meanwhile, rare earth elements can cause hepatotoxicity in rats (Yumiko et al., 1997). Excess yttrium was demonstrated to cause changes in some gene expressions and have undesirable effects on DNA transcription factors in rats (Yang et al., 2006). Although these adverse effects of such elements in magnesium alloys were not shown in humans, some researchers are already trying to avoid using them by utilizing other molecules such as calcium, zinc, and manganese, that are known to be better tolerated by the body (Xu et al., 2007; Li et al., 2008). Zinc, for example, is an abundant nutritional element and is known to be generally well tolerated in the body (Tapiero and Tew, 2003). Moreover, it was found that addition of zinc to magnesium alloys can increase corrosion resistance and strengthen them (Zhang et al., 2009). The latter authors obtained a zinc containing $(6 \%$, w/w) magnesium alloy with ca. $42.3 \mathrm{GPa}$ modulus of elasticity, $279 \mathrm{MPa}$ tensile strength, and 434 MPa compressive strength; which showed that this biomaterial is mechanically compatible with bone.

\section{Conclusion}

Advances in materials science and technology and a better understanding of the nature of bone help us design more compatible hard tissue implants, both biologically and mechanically. There are different classes of biodegradable materials already available, at least conceptually, that may serve these purposes. Biodegradable polymers constitute a group of materials with diverse properties. They may be flexible or rigid; they may be elastic or not, and they are resilient in general. They can be produced to have similar properties with some biological materials of different physical properties. Their production methodologies are flexible, so that they may be blended, copolymerized, or crosslinked in order to obtain different chemical and physical characteristics. Although they found a high number of application areas as biomaterials, this is not valid especially in bone implants due to their low mechanical properties. Except for some extremely crystalline types, they usually undergo plastic deformation under high stress levels that could result from normal activities of skeletal system. Therefore, blends of crystalline and amorphous polymers with optimized mechanical properties find use in a number of hard tissue implants. Use of crystalline polymers, however, raise immunogenicity issues due to their low rate of degradation. Biodegradable polymers have great potential as hard tissue implants but some problems still need to be resolved.

On the other hand, bioceramics, like the bone itself obtained from animals or cadavers, or from seashells were the first implant materials to serve this purpose due to their immediate availability. The problem with them, however, is that bone obtained from cadavers is brittle when dry or may be immunogenic or even toxic when wet. Synthetic or natural ceramic bone analogs or fixtures basically share the same mechanical properties with dry bone. Due to their chemical similarities to bone, however, calcium phosphate ceramics can increase the biocompatibility of other implant materials when used as coating on 
them. Such uses constitute the most common way of utilizing them as bone biomaterials.

Biodegradable metals constitute the most recent class of materials in hard tissue implants that came after discovery of advanced alloying techniques. This enabled elongation of the very high degradability issues that is inherent with magnesium implants, which constitute the most prominent example of this class of materials. The inherent rapid hydrogen gas release problem of magnesium in physiological fluids was reported to be overcome in recent studies. Different compositions in magnesium alloys enabled production of implants that can mechanically better match to bone. The fast progress in the biodegradable metals indicates the high potential of these as bone implants.

Production of biodegradable hard tissue implants is a challenging field of research where there is no one perfect material or production method yet that fits perfectly to the complex needs of bone healing process. Advances in engineering technologies and our understanding of bone biology will certainly enlighten our way to the ultimate bone implant. The new solutions can be found in the biomimetic composites like the original bone itself and benefit from what nano- and microtechnology started to offer such as nanoparticles, and patterned surfaces carrying bone inducing bioactive species.

\section{References}

Barber F.A., Elrod B.F., McGuire D.A., Paulos L.E. (1995) Preliminary results of an absorbable interference screw. Arthroscopy: The Journal of Arthroscopic \& Related Surgery. 11(5): 537-548.

Basmanav F.B., Kose G.T., Hasirci V. (2008) Sequential growth factor delivery from complexed microspheres for bone tissue engineering. Biomaterials. 29(32): 4195-4202.

Bayston R., Nuradeen B., Ashraf W., Freeman B.J.C. (2007) Antibiotics for the eradication of Propionibacterium acnes biofilms in surgical infection. J. Antimirob. Chemother. 60: 1298-1301

Bergsma J.E., de Bruijn W.C., Rozema F.R., Bos R.R.M., Boering G. (1995) Late degradation tissue response to poly(L-lactide) bone plates and screws. Biomaterials. 16(1): 25-31.

Bohner M. (2000) Calcium orthophosphates in medicine: from ceramics to calcium phosphate cements. Injury. 31(4): D37-47.

Buijs G.J., Van der Houwen E.B., Stegenga B., Bos R.R.M., Verkerke G.J. (2007) Mechanical Strength and Stiffness of Biodegradable and Titanium Osteofixation Systems. J. Oral Maxillofac. Surg. 65(11): 2148-2158.

Cheung L.K., Chow L.K., Chiu W.K. (2004) A randomized controlled trial of resorbable versus titanium fixation for orthognathic surgery. Oral. Surg. Oral. Med. Oral. Pathol. Oral. Radio.l Endod. 98: 386-397.

Chu T.M.G., Warden S.J., Turner C.H., Stewart R.L. (2007) Segmental bone regeneration using a load-bearing biodegradable carrier of bone morphogenetic protein-2. Biomaterials 28(3): 459-467.

D’Antonio J.A., Sutton K. (2009) Ceramic materials as bearing surfaces for total hip arthroplasty. J. Am. Acad. Orthop. Surg.17(2): 63-68.

El-Rahman S.S.A. (2003)Neuropathology of aluminum toxicity in rats (glutamate and GABA impairment). Pharmacol. Res. 47(3): 189-94.

Eppley B.L., Morales L., Wood R., Pensler J., Goldstein J., Havlik R.J. et al. (2004) Resorbable PLLA-PGA plate and screw fixation in pediatric craniofacial surgery: clinical experience in 1883 patients. Plast. Reconstr Surg. 114: 850-856. 
Fleck C., Eifler D. (2010) Corrosion, fatigue and corrosion fatigue behaviour of metal implant materials, especially titanium alloys. Int. J. Fatig. 32(6):929-935.

Gu X., Zheng Y., Zhong S., Xi T., Wang J., Wang W. (2009) Corrosion of, and cellular responses to $\mathrm{Mg}-\mathrm{Zn}-\mathrm{Ca}$ bulk metallic glasses. Biomaterials. doi:10.1016/j.biomaterials.2009.11.015.

Hänzi A.C., Gerber I., Schinhammer M., Löffler J.F., Uggowitzer P.J. (2009) On the in vitro and in vivo degradation performance and biological response of new biodegradable Mg-Y-Zn alloys. Acta Biomater. doi: 10.1016/j.actbio.2009.10.008.

Hartwig A. (2001) Role of magnesium in genomic stability. Mutat. Res./Fund. Mol. Mech. Mutagen. 475: 113-121.

Hasirci V., Lewandrowski K.U., Bondre S.P., Gresser J.D., Trantolo D.J., Wise D.L. (2000) High strength bioresorbable bone plates: preparation, mechanical properties and in vitro analysis. Biomed. Mater. Eng. 10:19-29.

Hutchens S.A., Benson R.S., Evans B.R., Rawn C.J., O’Neill H. (2009) A resorbable calciumdeficient hydroxyapatite hydrogel composite for osseous regeneration. Cellulose. 16: 887-898.

Kaeding C., Farr J., Kavanaugh T., Pedroza A. (2005) A prospective randomized comparison of bioabsorbable and titanium anterior cruciate ligament interference screws. Arthroscopy 21(2): 147-51.

Karageorgiou V., Kaplan D. (2005) Porosity of 3D biomaterial scaffolds and osteogenesis. Biomaterials. 26: 5474-5491.

Kim Y.K., Yeo H.H., Lim S.C. (1997) Tissue response to titanium plates: a transmitted electron microscopic study. J. Oral Maxillofac. Surg. 55: 322-326.

Konan S., Haddad F.S. (2009) A clinical review of bioabsorbable interference screws and their adverse effects in anterior cruciate ligament reconstruction surgery. The Knee. 16:6-13.

Ku C.-H., Pioletti D.P., Browne M., Gregson P.J. (2002) Effect of different Ti-6Al-4V surface treatments on osteoblasts behavior. Biomaterials. 23(6): 1447-1454.

Lactosorb brochure "Lorenz Plating System Lactosorb". Web 8 April 2010. <http://www. lorenzsurgical.com/downloads/BMF-7109\%20Lactosorb_Bro_final0108.pdf>.

Lambotte A. (1932) L'utilisation du magnesium comme materiel perdu dans l'osteosynthe' se. Bull. Me'm. Soc. Nat. Chir. 28: 1325-1334.

LeGeros R.Z. (2008) Calcium Phosphate-Based Osteoinductive Materials. Chem. Rev. 108: 47424753.

Li Z., Gu X., Lou S., Zheng Y. (2008) The development of binary $\mathrm{Mg}-\mathrm{Ca}$ alloys for use as biodegradable materials within bone. Biomaterials. 29(10): 1329-1344.

Ma C.B., Francis K., Towers J., Irrgang J., Fu F.H., Harner C.H. (2004) Hamstring anterior cruciate ligament reconstruction: a comparison of bioabsorbable interference screw and endobuttonpost fixation. Arthroscopy. 20(2): 122-128.

McBride E.D. (1938) Absorbable metal in bone surgery. J. Am. Med. Assoc. 111: 2464-2467.

McCord C.P. 1(942) Chemical gas gangrene from metallic magnesium. Ind. Med. 11:71-79.

Mine Y., Makihira S., Nikawa H., Murata H., Hosokawa R., Hiyama A., Mimura S. (2010) Impact of titanium ions on osteoblast-, osteoclast- and gingival epithelial-like cells. J. Prosthodent. Res. 54:1-6.

Moon S.M., Ingalhalikar A., Highsmith J.M., Vaccaro A.R. (2009) Biomechanical rigidity of an allpolyetheretherketone anterior thoracolumbar spinal reconstruction construct: an in vitro corpectomy model. Spine J. 9(4): 330-335. 
Nagels J., Stokdijk M., Rozing P.M. (2003) Stress shielding and bone resorption in shoulder arthroplasty. J. Shoulder Elbow Surg.12: 35-9.

Niinomi M. (2008) Metallic biomaterials. J. Artif. Organs. 11: 105-110.

Paavolainen P., Karaharju E., Slatis P., Ahonen J., Holmstrom T. (1978) Effect of rigid plate fixation on structure and mineral content of cortical bone. Clin. Orthop. Relat. Res. 136: 287-293.

Perrin D.E., English J.P. (1997) Polyglycolide and Polylactide. In: Handbook of Biodegradable Polymers (Domb A.J., Kost J., Wiseman M.W., Eds). Amsterdam, Harwood Academic Publishers. p. 2-27.

Pietrzak W., Kumar M. (2009) An enhanced strength retention poly(glycolic acid)-poly(L-lactic acid) copolymer for internal fixation: in vitro characterization of hydrolysis. J. Craniofac. Surg. 20(5): 1533-1537.

Ramay H.R.R., Zhang M. (2004) Biphasic calcium phosphate nanocomposite porous scaffolds for load-bearing bone tissue engineering. Biomaterials. 25: 5171-5180.

Shin H., Jo S., Mikos A.G. (2003) Biomimetic materials for tissue engineering. Biomaterials. 24: 4353-4364.

Song G., Atrens A. (2003) Understanding magnesium corrosion-a framework for improved alloy performance. Adv. Eng. Mater. 5(12): 837-858.

Staiger M.P., Pietak A.M., Huadmai J., Dias G. (2006) Magnesium and its alloys as orthopedic biomaterials: A review. Biomaterials. 27: 1728-1734

Suchanek W.L., Yoshimura M. (1998) Processing and properties of hydroxyapatite-based biomaterials for use as hard tissue replacement implants. J. Mater. Res. 13: 94-117.

Tapiero H., Tew K.D. (2003) Trace elements in human physiology and pathology: zinc and metallothioneins. Biomed. Pharmacother. 57(9): 399-411.

Thomas M.V., Puleo D.A., Al-Sabbagh M. (2005) Bioactive glass three decades on. J. Long-Term Eff. Med. 15(6): 585-597.

Vormann J. (2003) Magnesium: nutrition and metabolism. Mol. Aspects Med. 24: 27-37.

Witte F., Kaese V., Haferkamp H., Switzer E., Meyer-Lindenberg A., Wirtha C.J., Windhagen H. (2005) In vivo corrosion of four magnesium alloys and the associated bone response. Biomaterials. 26: 3557-3563.

Wolf F.I., Cittadini A. (2003) Chemistry and biochemistry of magnesium. Mol. Aspects Med. 24: 3-9.

Xu L.P., Yu G.N., Zhang E., Pan F., Yang K. (2007) In vivo corrosion behavior of Mg-Mn-Zn alloy for bone implant application. J. Biomed. Mater. Res. A. 83A(3): 703-711.

Yang W., Zhang P., Liu J., XueY. (2006) Effect of long-termintake ofY3+ in drinking water on gene expression in brains of rats. J. Rare Earth. 24(3): 369-373.

Yaremchuk M.J., Posnick J.C. (1995) Resolving controversies related to plate and screw fixation in the growing craniofacial skeleton. J. Craniofac. Surg. 6:525-538.

Yaszemski M.J., Payne R.F., Hayes W.C., Lander R., Mikos A.G. (1996) Evolution of bone transplantation: molecular, cellular and tissue strategies to engineer human bone. Biomaterials. 17: 175-185.

Yilgor P., Tuzlakoglu K., Reis R.L., Hasirci N., Hasirci V. (2009) Incorporation of a sequential BMP-2/BMP-7 delivery system into chitosan-based scaffolds for bone tissue engineering. Biomaterials. 30(21): 3551-3559. 
Yumiko N., Yukari T., Yasuhide T., Tadashi S., Yoshio I. (1997) Differences in behavior among the chlorides of seven rare earth elements administered intravenously to rats. Fundam. Appl. Toxicol. 37: 106-116.

Zberg B., Uggowitzer P.J., Löffler J.F. (2009) MgZnCa glasses without clinically observable hydrogen evolution for biodegradable implants. Nature Materials. 8: 887-891.

Zhang S., Zhang X., Zhao C., Li J., Song Y., Xie C., Tao H., Zhang Y., He Y., Jiang Y., Bian Y. (2009) Research on an Mg-Zn alloy as a degradable biomaterial. Acta Biomater. doi:10.1016/j. actbio.2009.06.028.

\title{
Биоразлагаемые имплантаты для твердых тканей
}

\author{
Е. Айдин \\ а МЭТУ, БиоМАТ, отдел биотехнологии, \\ Биотехнологическое исследовательское объединение, \\ 06531, Анкара, Турияия \\ ${ }^{\sigma}$ МЭТУ, БиоМАТ, отдел биологических наук, \\ Биотехнологическое исследовательское объединение, \\ 06531, Анкара, Туричи
}

Старение населения и уменьшение физических нагрузок вследствие повышения уровня жизни являются превалирующими и неизбежными факторами, ведущими к уменьшению костной массы, минеральной составляющей костной ткани, а также снижению мымечной силы у современного человека. В результате этого увеличивается частота переломов на протяжении жизни. Хотя костная ткань обладает способностью к регенерации, сравнимой с другими тканями организма, существуют специфические особенности для восстановления ее иелостности - сопоставление и фиксация отломков костей на время, необходимое для заживления. Разработаны различные технологии и средства, для придания заменителям костной ткани необходимых свойств. Большинство доступных средств фиксации изготавливают из некорродирующих металлов по причине их твердости и прочности, т.е. свойствам, обеспечивающим скелетной системе способность нести механическую нагрузку. В идеале, фиксирующий имплант должен быть временным, с возможностью удаления после восстановления нормальных функиий, для предотвращения развития таких осложнений, как развитие имплантат-ассочиированных инфекций на поздних стадиях, резорбция кости или иммунные реакции. Операции по удалению фиксирующих имплантатов, вживленных в кость, нередко ведут к серьезным повреждениям новообразованной ткани костной мозоли. Другая, не менее важная проблема при фиксации металлическими средствами заключается в том, что металл обладает более высокими прочностными характеристиками по сравнению с костной тканью. Вследствие этого свойства металлических протезов механический стимул, являющийся необходимой физиологической составляющей для полноценности формирующейся кости, отсутствует. Исходя из необходимости решения данных проблем, предлагается использовать различные биодеградируемые и биоразлагаемые материаль для изготовления фиксирующих устройств при переломах кости. В статье дан обзор развития и трендов в области биодеградируемых имплантатов для твердых тканей, применяющихся материалов и их совместимости с костной тканью.

Ключевые слова: имплантаты для твердых тканей, биодеградируемые полимеры, биоразлагаемая керамика, биодеградируемые металлы, биомеханика, биосовместимость. 